\title{
INFECTIONS IN POLISH PEDIATRIC HEMATOLOGY, ONCOLOGY AND STEM CELL TRANSPLANTATION CENTERS IN 2012-2013: INCIDENCE REPORT
}

\section{ZAKAŻENIA W POLSKICH PEDIATRYCZNYCH OŚRODKACH HEMATOLOGII, ONKOLOGII I PRZESZCZEPIANIA KOMÓREK KRWIOTWÓRCZYCH W LATACH 2012-2013: EPIDEMIOLOGIA}

Department of Pediatric Hematology and Oncology

Collegium Medicum, Nicolaus Copernicus University, Bydgoszcz

Head of Department: prof. Mariusz Wysocki

Jurasz University Hospital nr 1, Bydgoszcz

Director: mgr Jacek Kryś

(*) Full list of investigators is provided in the Appendix

\section{S u m m a r y}

B ackground. Infections are the main cause of morbidity and mortality in children with cancer or undergoing stem cell transplantation.

$\mathrm{Objective.} \mathrm{The} \mathrm{aim} \mathrm{of} \mathrm{this} \mathrm{study} \mathrm{was} \mathrm{the} \mathrm{analysis} \mathrm{of}$ incidence and outcome of bacterial, fungal and viral infections in Polish centers of pediatric hematology and oncology (PHO) and pediatric hematopoietic stem cell transplantation (HSCT) units over a period of 24 months: iPhot-13 project.

Patients and methods. During the analyzed period a total number of 1768 patients were newly-diagnosed for malignancy and 308 HSCTs were performed in participating centers. A total number of 2556 infections were reported.

Results. The incidence of patients with at least one episode of microbiologically documented infections with bacteria etiology was $26.3 \%$ among children undergoing chemo- and/or radiotherapy, and $34.1 \%$ among children undergoing hematopoietic stem cell transplantation. The incidence of patients with at least one episode of fungal infection was $7.6 \%$ among children undergoing chemoand/or radiotherapy, and $27.3 \%$ among children undergoing hematopoietic stem cell transplantation. The incidence of IFI was prominently high in ALL (13.0\% in PHO setting, and $31.3 \%$ in HSCT setting) and AML patients (43.2\% in PHO, and $44.7 \%$ in HSCT setting). Viral infections reached $9.3 \%$ of patients in PHO setting, including a group of previously transplanted patients. The incidence of viral infections in HSCT setting reached $41.2 \%$. This rate reached $51.3 \%$ children after allo-HSCT and $10.5 \%$ after auto-HSCT.

Conclusions. Emerging data from Polish pediatric oncohematology and hematopoietic stem cell transplant centers indicate high incidence of infectious complications in pediatric population. Rate of bacterial infections is similar to those reported in international studies. The incidence of IFI in ALL and AML is much higher than it was recently anticipated. Viral infections occur in half of transplant patients and might severely compromise the benefit of transplant.

\section{Streszczenie}

W stęp. Zakażenia mogą być częstą przyczyną chorobowości i śmiertelności wśród dzieci z chorobami nowotworowymi lub poddawanymi przeszczepieniu komórek krwiotwórczych.
C e 1. Analiza częstości i zejścia zakażeń bakteryjnych, grzybiczych i wirusowych w polskich pediatrycznych ośrodkach onkohematologii (PHO) i/lub przeszczepiania komórek krwiotwórczych (HSCT) w okresie 24 miesięcy: projekt iPhot-13. 
Pacjenci i metodyka. W badanym okresie w ośrodkach uczestniczących w projekcie u 1768 dzieci rozpoznano chorobę nowotworową oraz wykonano 308 HSCT. Zgłoszono 2556 przypadków zakażeń.

W y niki. Odsetek pacjentów z co najmniej jednym epizodem zakażenia bakteryjnego wynosi $26,3 \%$ wśród dzieci z oddziałów PHO oraz 34,1\% wśród dzieci po HSCT. Częstość inwazyjnych zakażeń grzybiczych wynosi 7,6\% u pacjentów PHO oraz 27,3\% wśród dzieci po HSCT. Częstość IFI była szczególnie wysoka u dzieci z ALL (PHO-13,0\%, HSCT-31,3\%) i AML (PHO-43,2\%, HSCT-44,7\%). Zakażenia wirusowe wystąpiły u 9,3\% dzieci z oddziałów
PHO. Częstość zakażeń wirusowych po HSCT wyniosła $41,2 \%$, w tym $51,3 \%$ po allo-HSCT oraz $10,5 \%$ po autoHSCT.

Wnioski. Pojawiające się dane $z$ polskich pediatrycznych ośrodków PHO i HSCT wskazują na wysoką częstość powikłań infekcyjnych w populacji dziecięcej. Odsetek zakażeń bakteryjnych jest porównywalny do danych międzynarodowych. Częstość zakażeń grzybiczych jest wyższa niż dane dostępne $\mathrm{z}$ ostatniej dekady. Infekcje wirusowe występują u połowy pacjentów HSCT i mogą niweczyć efekt wykonanych transplantacji.

Key words: bacterial infections, invasive fungal infections, viral infections, malignant diseases, oncohematology, hematopoietic stem cell transplantation, children

Słowa kluczowe: zakażenia bakterie, inwazyjne zakażenia grzybicze, zakażenia wirusowe, choroby nowotworowe, onkohematologia, przeszczepianie komórek krwiotwórczych, dzieci

\section{INTRODUCTION}

Infections are the main cause of morbidity and mortality in patients with cancer or undergoing stem cell transplantation [1]. Children with hematologic malignancies are especially susceptible to bacterial, fungal and viral infections due to abnormality of the basic mediators of immunity. Factors that predispose a child to infection include: alterations of the body's natural barriers, presence of central venous catheters, alteration of the innate immune system and acquired immunity, and intensive oncologic and supportive therapy.

No analysis on epidemiology of infections in pediatric hematology, oncology or stem cell transplantation in Poland had been performed until an initiative within Polish Society of Pediatric Oncology and Hematology was undertaken in 2013 to collect data on infections in pediatric hematology, oncology and stem cell transplant unit. This project was named: Infections in Polish pediatric hematology, oncology and stem cell transplant setting 2013 (iPhot-13).

The objective of this study was the analysis of incidence and outcome of bacterial, fungal and viral infections in Polish centers of pediatric hematology and oncology (PHO) and pediatric hematopoietic stem cell transplantation (HSCT) units over a period of 24 months (2012-2013).

\section{PATIENTS AND METHODS}

14 pediatric centers of hematology and oncology and 5 pediatric stem cell transplantation units participated in this retrospective study. Bacterial, fungal and viral infections were reported in each participating center and data were sent to Chair of
Pediatrics, Hematology and Oncology in Collegium Medicum in Bydgoszcz, which coordinated this project (iPhot-13).

All consecutive infections with 'alert pathogens' as well as selected viral infections diagnosed between 1.01.2012-31.12.2013 were included into the study. Patients undergoing HSCT were included into standard anti-infectious prophylactic procedures [2]

Bacterial and fungal infections reported as 'alert pathogens' listed in the Official Journal of Law (Dziennik Ustaw; Dz.U. z 2011 nr 294 poz. 1741; Supplement 1) were the subject of the analysis (Table 1). Viral infections were reported also according to this list and supplemented by infections caused by: herpesviruses (except herpes simplex virus), adenovirus, polyomavirus BKV, and influenza.

\section{STATISTICAL ANALYSIS}

Basic characteristics and outcome of infections were analyzed for all reported cases of infections. Incidence of infections was analyzed only for the first (bacterial, fungal or viral) infection, only for patients with newly diagnosed malignant disease between 1.01.2012-31.12.2013 in PHO setting and for transplants performed in this period for HSCT setting. Categorical variables were compared with chi-square test, while non-categorical variables were compared with Mann-Whitney U test. Incidence, cumulative incidence of infections and survival from infections were determined by Kaplan-Meier method and compared with log-rank test. All reported p-values are two-sided; $\mathrm{p}<0.05$ was considered as statistically significant. 
Table 1. List of alert pathogens

Tabela 1. Lista czynników alarmowych

\begin{tabular}{|l|l}
\hline No & Alert pathogen \\
\hline
\end{tabular}

Lp Drobnoustrój alarmowy

Staphylococcus aureus resistant to methicillin (MRSA) or glycopeptides (VISA or VRSA) or oxazolidinones;

Gronkowiec złocisty (Staphylococcus aureus) oporny na

1 metycylinę (MRSA) lub glikopeptydy (VISA lub VRSA) lub oksazolidynony;

Enterococcus spp. resistant to glycopeptides (VRE) or oxazolidinones;

Enterokoki (Enterococcus spp.) oporne na glikopeptydy (VRE)

2 lub oksazolidynony;

Enterobacteriaceae spp. Bacteria producing extended spectrum of beta-lactamases (e.g. ESBL, AMPC, KPC) or resistant to carbapenems or two other groups of antibiotics or polymyxins; pałeczki Gram-ujemne Enterobacteriaceae spp. wytwarzające

3 betalaktamazy o rozszerzonym spektrum substratowym (np. ESBL, AMPC, KPC) lub oporne na karbapenemy lub inne dwie grupy leków lub polimyksyny;

Pseudomonas aeruginosa strains resistant to carbapenems or two other groups of antibiotics or polymyxins;

4 pałeczka ropy błękitnej (Pseudomonas aeruginosa) oporna na karbapenemy lub inne dwie grupy leków lub polimyksyny;

non-fermenting strains Acinetobacter spp. resistant to carbapenems or two other groups of antibiotics or polymyxins;

5 pałeczki niefermentujace Acinetobacter spp. oporne na karbapenemy lub inne dwie grupy leków lub polimyksyny;

pathogenic strains of anaerobic bacteria Clostridium difficile and their toxins A or B;

6 szczepy chorobotwórcze laseczki beztlenowej Clostridium difficile oraz wytwarzane przez nie toksyny A i B;

anaerobic bacteria Clostridium perfringens;

7 laseczka beztlenowa Clostridium perfringens;

Streptococcus pneumoniae resistant to cephalosporines III generation or penicillin;

dwoinka zapalenia płuc (Streptococcus pneumoniae) oporna na

8 cefalosporyny III generacji lub penicylinę;

fungi Candida resistant to fluconazole or other azoles or candines;

Grzyby Candida oporne na flukonazol lub inne leki z grupy

9 azoli lub kandyn;

fungi Aspergillus;

10 grzyby Aspergillus;

rotavirus;

11 rotawirus;

norovirus;

12 norowirus;

respiratory syncytial virus (RSV);

13 wirus syncytialny (RSV);

hepatitis B virus (HBV);

14 wirus zapalenia wątroby typu B (HBV); hepatitis $\mathrm{C}$ virus (HCV);

15 wirus zapalenia wątroby typu C (HCV):

human immunodeficiency virus (HIV);

16 wirus nabytego niedoboru odporności u ludzi (HIV);

pathogens isolated from blood or cerebro-spinal fluid, causing generalized or invasive infection;

biologiczne czynniki chorobotwórcze izolowane z krwi lub

17 płynu mózgowo-rdzeniowego, odpowiedzialne za uogólnione lub inwazyjne zakażenia.

Table 2. Incidence of infections in patients $\mathrm{PHO}$ and HSCT centers

Tabela 2. Częstość zakażeń u pacjentów w ośrodkach PHO $i$ HSCT

\begin{tabular}{|l|c|c|}
\hline Infections & PHO & HSCT \\
\hline Bacterial & $26.3 \%$ & $34.1 \%$ (allo-35.8\%; auto-30.3\%) \\
\hline Fungal & $7.6 \%$ & $27.3 \%$ (allo-30.6\%; auto-17.1\%) \\
\hline Viral & $9.3 \%$ & $41.2 \%$ (allo-51.3\%; auto-10.5\%) \\
\hline
\end{tabular}

\section{RESULTS}

\section{Demographics}

Over a period of 24 consecutive months between 101-2012 and 31-12-2013, a total number of 1768 patients were newly diagnosed for malignancy in 14 centers of pediatric hematology and oncology, including 430 with ALL (acute lymphoblastic leukemia), 81 with AML (acute myeloblastic leukemia), 108 with NHL (non-Hodgkin lymphoma), 110 with HD (Hodgkin disease) and 1012 with solid tumors. During this period, a total number of 308 hematopoietic stem cell transplantations (HSCT) were performed in 5 transplant centers.

\section{Infections}

During this period, following total number of 2556 infections were reported, including 1343 bacterial, 286 fungal, and 259 viral ones in PHO centers, and 281 bacterial, 126 fungal, and 261 viral infections in HSCT centers. Total number of reported infections included also multiple infections, recurrent infections (with the same or other pathogen) and colonizations.

\section{Bacterial infections in PHO centers}

A total number of 1343 records on bacterial infections were reported in 2012-2013. Median time from the diagnosis of malignancy to occurrence of infection was 4.5 (0-91) months, median time of therapy 10 (0-93) days. Survival rate after bacterial infections was $98.2 \%$. A total number of 1191 bacterial strains were identified, including 456 (38.3\%) with MDR phenotype.

A total number of patients newly-diagnosed for malignancy after 1.01.2012 with at least one bacterial infection were 465 . The overall incidence of bacterial infections was $26.3 \%(465 / 1768)$ (Table 2), with incidence of $40.9 \%$ (176/430) for ALL, $58.0 \%$ (47/81) for AML, $37.0 \%(40 / 108)$ for NHL, $12.7 \%$ (14/110) for HD and $15.6 \%$ (158/1012) for solid tumors.

\section{Bacterial infections in HSCT centers}

A total number of 281 records on bacterial infections were reported in 2012-2013. After exclusion of multiple data, 189 bacterial infections, 55 colonizations and one case of tuberculosis were defined. Median time from transplantation to occurrence of infection was 0.6 (-1.9-23) month, median time of therapy 14 (1-196) days. Survival rate after bacterial infections was $96.0 \%$. A total number of 
190 bacterial strains were identified, including 146 (76.8\%) with MDR phenotype.

A total number of patients transplanted after 1.01.2012 with at least one bacterial infection were 105. The overall incidence of bacterial infections was $34.1 \%$ (105/308), with incidence $35.8 \%$ (83/232) for allo-HSCT, $30.3 \%$ (23/76) for auto-HSCT, $43.3 \%$ $(29 / 67)$ for ALL, $23.8 \%$ (14/47) for AML, $18.5 \%$ $(5 / 27)$ for NHL/HD and $15.8 \%(6 / 38)$ for SAA (severe aplastic anemia).

\section{Fungal infections in PHO centers}

A total number of 286 records on fungal infections were reported in 2012-2013. After exclusion of multiple data and FUO episodes, 231 fungal infections were defined, including 39 proven, 53 probable and 139 possible IFI (invasive fungal infections). The total number of IFI was 103 in 2012 and 128 in 2013 . Out of this number, $71.4 \%(165 / 231)$ of the IFI was reported in acute leukemia patients: 102 in ALL (9 proven, 30 probable and 63 possible), and 63 in AML ( 8 proven, 13 probable and 42 possible).

A total number of patients newly-diagnosed for malignancy after 1.01.2012 with at least one IFI were 136 (21 proven, 32 probable, 94 possible). The incidence of IFI among PHO patients was $7.6 \%$ (136/1768), including proven IFI in $1.2 \%$ (21/1768), probable IFI in $1.8 \%(32 / 1768)$, and possible IFI in $5.3 \%(94 / 1768)$ patients. The incidence of IFI among ALL patients was $13.0 \%$ (56/430), including proven IFI in $0.7 \%$ (3/430), probable IFI in $4.1 \%$ (18/430), and possible IFI in $9.5 \%$ (41/430) patients. The incidence of IFI among AML patients was $43.2 \%$ $(35 / 81)$, including proven IFI in $2.4 \%$ (2/81), probable IFI in $9.8 \%(8 / 81)$, and possible IFI in $34.6 \%(28 / 81)$ patients.

Data on survival from IFI were available for 127 patients, with positive outcome in $90.6 \%$ (115/127) patients. The rate of survival from IFI was $88.2 \%$ $(15 / 17)$ for proven IFI, $88.9 \%$ (24/27) for probable IFI and $91.6 \%(76 / 83)$ for possible IFI $(\mathrm{p}=\mathrm{ns})$. Combined antifungal therapy was administered in 34 cases, with positive outcome in $88.2 \%(30 / 34)$ cases, in comparison to $93.4 \%(85 / 91)$ of survival rate for patients on monotherapy $(\mathrm{p}=\mathrm{ns})$.

\section{Fungal infections in HSCT centers}

A total number of 126 records on fungal infections were reported in 2012-2013. After exclusion of multiple data and FUO episodes, 116 fungal infections were defined, including 13 proven, 48 probable and 55 possible. The total number of IFI was 45 in 2012 and 71 in 2013. Half (58/116) of the IFI cases were reported in acute leukemia patients: 30 in ALL (5 proven, 11 probable and 14 possible) and 28 in AML (3 proven, 9 probable and 16 possible).

A total number of patients transplanted after 1.01.2012 with at least one IFI were 84 (11 proven, 29 probable, 44 possible). The incidence of IFI among HSCT patients was $27.3 \%$ (84/308), including proven IFI in $7.1 \%$ (22/308), probable IFI in $9.4 \%$ (29/308), and possible IFI in $14.3 \%$ (44/308) patients. The incidence of IFI among allo-HSCT patients was $30.6 \%$ $(71 / 232)$, including proven IFI in $3.4 \%$ (8/232), probable IFI in $12.1 \%(28 / 232)$, and possible IFI in $15.1 \%(35 / 232)$ patients. The incidence of IFI among auto-HSCT patients was $17.1 \%$ (13/76), including proven IFI in $3.9 \%(3 / 76)$, probable IFI in $1.3 \%$ (1/76), and possible IFI in $11.8 \%(9 / 76)$ patients. The incidence of IFI among ALL patients was 31.3\% $(21 / 67)$, including proven IFI in $4.5 \%$ (3/67), probable IFI in $13.4 \%(9 / 67)$, and possible IFI in $13.4 \%(9 / 67)$ patients. The incidence of IFI among AML patients was $44.7 \%$ (21/47), including proven IFI in $6.4 \%$ (3/47), probable IFI in $12.8 \%(6 / 47)$ and possible IFI in $25.5 \%$ (12/47) patients.

Data on survival from IFI were available for 76 patients, with positive outcome in $77.6 \%$ (59/76) patients. The rate of survival from IFI was $90.9 \%$ (10/11) for proven IFI, $67.9 \%$ (19/28) for probable IFI and $81.1 \%(30 / 37)$ for possible IFI $(p=n s)$. Combined antifungal therapy was administered in 16 cases, with positive outcome in $93.8 \%(15 / 16)$ cases, in comparison to $79.2 \%(38 / 48)$ of survival rate for patients on monotherapy $(\mathrm{p}=0.052)$. No statistical differences were observed in survival rate from IFI between auto- vs allo-HSCT patients, as well as between ALL vs AML patients. Kaplan-Meier analysis of survival from IFI in 98 available cases showed probability of survival at $75.5 \%(0.75 \pm 0.04)$, and $92.3 \%, 61.5 \%$, and $82.6 \%$ for proven, probable and possible IFI, respectively.

\section{Viral infections in $\mathrm{PHO}$ centers}

A total number of 259 records on viral infections were reported in 2012-2013. After exclusion of excess data (e.g. on HSV), a total number of 251 viral infections were analyzed, including 152 rotavirus (RV), 38 cytomegalovirus (CMV), 15 influenza (FLU), 14 varicella-zoster (VZV), 12 Epstein-Barr virus 
(EBV), 11 adenovirus (ADV), 4 respiratory syncytial virus (RSV), 2 polyomavirus (BKV), 1 hepatitis $\mathrm{B}$ virus (HBV), 1 hepatitis $\mathrm{C}$ virus (HCV), and 1 human herpesvirus-6 (HHV6). The latent infections occurred in children at all ages, with median age 9.0 years for CMV; 7.1 years for EBV; 14.8 years for BKV and 10.7 years for VZV. However, RV and sporadic respiratory viruses affected mainly younger children, with median age of 2.8 years for RV; 3.0 years for ADV; 3.0 years for FLU and 3.5 years for RSV.

A total number of patients newly-diagnosed for malignancy after 1.01.2012 with at least one viral infection were 165 . The overall incidence of viral infections was $9.3 \%$ (165/1768), with incidence of $5.7 \%(100 / 1768)$ for rotavirus, $0.7 \%(13 / 1768)$ for FLU, $0.4 \%$ (7/1768) for ADV, $0.2 \%$ (4/1768) for RSV, $1.0 \%(17 / 1768)$ for CMV, $0.6 \%(10 / 1768)$ for $\mathrm{EBV}$, $0.5 \%(9 / 1768)$ for $\mathrm{VZV}$ and $0.1 \%(1 / 1768)$ for $\mathrm{BKV}$, HHV6, HBV and HCV.

Survival rate was $80 \%(12 / 15)$ for patients with influenza, and $100 \%$ for all other viral infections in PHO setting.

\section{Viral infections in HSCT centers}

In HSCT setting, viruses are divided as latent (herpesviruses and BKV) and sporadic (ADV, RV, FLU and CARV). A total number of 259 records on viral infections were reported in 2012-2013. After exclusion of excess and multiple data, a total number of 205 viral infections were analyzed, including 197 after 232 allo-HSCT, 8 after 76 auto-HSCT.

Infections occurred in $119(51.3 \%)$ allo-HSCT patients, and in $51.2 \%$ of them multiple infections were reported: infection with 1 virus was found in 58 patients, with 2 viruses in 29 , with 3 in 16 , and $>3$ in 16 patients. Cumulative incidence of viral infections in allo-HSCT was: CMV-28.0\%, BKV-18.5\%, EBV$15.5 \%$, ADV-9.5\%, RV-9.1\%, VZV-2.6\%, FLU-0.9\%, HHV6-0.9\%, HBV-0.3\%.

Following infections were reported in $8(10.5 \%)$ patients after auto-HSCT: RV-4, CMV-2, ADV-1, $B K V-1$. No differences were found between viral infections with respect to patient age and median time of infection after transplant (median time from 0,8 to 2,4 months), except for late VZV infections (median 6,5 months).

Survival rates were lowest after infections with EBV (90.7\%), ADV (93.8\%), BKV (94.2\%), and CMV (94.6\%), while it was $100 \%$ after FLU, HBV, VZV, HHV6 or RV infections.

\section{DISCUSSION}

This paper presents for the first time in our country, epidemiological data on infections in Polish pediatric oncohematology centers and hematopoietic stem cell transplant units. During the analyzed period of 24 months, the incidence of patients with at least one episode of microbiologically documented infections with bacteria etiology was $26.3 \%$ among 1768 children undergoing chemo- and/or radiotherapy, and 34.1\% among 308 children undergoing hematopoietic stem cell transplantation. These results match those obtained in studies performed by other centers [3-5]. Mikulska et al. showed documented bacterial blood-stream infections in 34\% HSCT patients, and the incidence of 35\% MDR bacteria among Gram-negative strains [3]. Gil et al. showed documented bacterial infections in $38.9 \%$ high-risk patients after auto-HSCT [5]. In Italian centers, the rate of MDR phenotype among Pseudomonas aeruginosa strains in children undergoing CHT or HSCT was 31.4\% [4].

The incidence of patients with at least one episode of fungal infection was $7.6 \%$ among children undergoing chemo- and/or radiotherapy, and $27.3 \%$ among children undergoing hematopoietic stem cell transplantation. The incidence of IFI was prominently high in ALL (13.0\% in PHO setting, and 31.3\% in HSCT setting) and AML patients (43.2\% in PHO, and $44.7 \%$ in HSCT setting). It seems that the incidences were higher than in previously reviewed data [6,7]. We also observed higher number of IFI in 2013 in comparison to the previous year. Importantly, the ratio of proven, probable and possible infections in Polish pediatric centers is comparable to data reported in international sources.

Viral infections were relatively infrequent in $\mathrm{PHO}$ setting, and reached $9.3 \%$ of patients, including a group of previously transplanted patients. It should be stressed that latent infections do not play a major role in PHO patients, thus infections with CMV, EBV and BKV have usually reactivated in patients after HSCT, previously treated in transplant centers. On the other hand, the incidence of viral infections in HSCT setting reached $41.2 \%$. This rate reached $51.3 \%$ children after allo-HSCT and $10.5 \%$ after auto-HSCT, and also multiple and recurrent viral infections occurred frequently. It is important to underline that infections with CMV, EBV, BKV or ADV resulted in 5-10\% of deaths due to respective virus. In many international reports it is stressed that viral infections after HSCT 
are an important issue and contribute to significant morbidity and mortality [8-12].

In conclusion, data emerging from Polish pediatric oncohematology and hematopoietic stem cell transplant centers indicate high incidence of infectious complications in pediatric population. Rate of bacterial infections is similar to those reported from international centers. With respect to fungal infections, our data suggest that the incidence of IFI in ALL and AML in both PHO and HSCT settings is much higher than it was recently anticipated. Finally, viral infections occur in half of transplant patients and might severely compromise the benefit of transplant.

Appendix: Participating investigators and institutions.

All listed investigators are co-authors of this paper: Jan Styczyński, Krzysztof Czyżewski, Mariusz Wysocki (Katedra Pediatrii, Hematologii i Onkologii, Szpital Uniwersytecki nr 1 im. Antoniego Jurasza, Collegium Medicum, Uniwersytet Mikołaja Kopernika, Bydgoszcz); Katarzyna Jachna-Sawicka, Eugenia Gospodarek (Katedra i Zakład Mikrobiologii, Szpital Uniwersytecki nr $1 \mathrm{im}$. Antoniego Jurasza, Collegium Medicum, Uniwersytet Mikołaja Kopernika, Bydgoszcz); Olga Gryniewicz-Kwiatkowska, Agnieszka Kołodziejczyk-Gietka, Bożenna Dembowska-Bagińska, Danuta Perek (Klinika Onkologii, Instytut-Pomnik Centrum Zdrowia Dziecka, Warszawa); Katarzyna Semczuk, Ewa Romanowska, Katarzyna Dzierżanowska-Fangrat (Zakład Mikrobiologii i Immunologii Klinicznej, InstytutPomnik Centrum Zdrowia Dziecka, Warszawa); Małgorzata Salamonowicz, Łukasz Hutnik, Michał Matysiak (Katedra i Klinika Pediatrii, Hematologii i Onkologii, Uniwersytet Medyczny, Warszawa); Edyta Podsiadły, Joanna Rogulska, Anna ChmielewskaSemkowicz, Urszula Demkow (Zakład Diagnostyki Laboratoryjnej i Immunologii Klinicznej Wieku Rozwojowego, Uniwersytet Medyczny, Warszawa); Agnieszka Zaucha-Prażmo, Jerzy Kowalczyk (Klinika Hematologii, Onkologii i Transplantologii Dziecięcej, Uniwersytet Medyczny, Lublin); Liliana ChełmeckaHanusiewicz, Walentyna Balwierz (Klinika Onkologii i Hematologii Dziecięcej, Polsko-Amerykański Instytut Pediatrii, Uniwersytet Jagielloński Collegium Medicum, Kraków); Karolina Siewiera, Jowita Frączkiewicz, Krzysztof Kałwak, Ewa Gorczyńska, Alicja Chybicka (Katedra i Klinika Transplantacji Szpiku, Onkologii i Hematologii Dziecięcej,
Uniwersytet Medyczny, Wrocław); Renata Tomaszewska, Tomasz Szczepański (Katedra i Klinika Pediatrii, Hematologii i Onkologii, Śląski Uniwersytet Medyczny, Zabrze); Olga Zając-Spychała, Anna Pieczonka, Jacek Wachowiak (Klinika Onkologii, Hematologii i Transplantologii Pediatrycznej, Uniwersytet Medyczny, Poznań); Ninela IrgaJaworska, Elżbieta Drożyńska (Katedra i Klinika Pediatrii, Hematologii, Onkologii, Uniwersytet Medyczny, Gdańsk); Marcin Płonowski, Maryna Krawczuk-Rybak (Klinika Onkologii i Hematologii Dziecięcej, Uniwersytet Medyczny, Białystok); Tomasz Ociepa, Tomasz Urasiński (Klinika Pediatrii, Hematologii i Onkologii, Pomorski Uniwersytet Medyczny, Szczecin); Filip Pierlejewski, Wojciech Młynarski (Klinika Pediatrii, Onkologii, Hematologii i Diabetologii, Uniwersytet Medyczny, Łódź); Zuzanna Gamrot, Maria Wieczorek (Oddział Hematologii i Onkologii Dziecięcej, Chorzowskie Centrum Pediatrii i Rehabilitacji im. dr E.Hankego, Chorzów); Zofia Małas, Wanda Badowska (Wojewódzki Specjalistyczny Szpital Dziecięcy, Oddział Hematologii i Onkologii, Olsztyn); Agnieszka Urbanek-Dądela, Grażyna Karolczyk (Oddział Hematologiczno-Onkologiczny, Wojewódzki Specjalistyczny Szpital Dziecięcy, Kielce); Weronika Stolpa, Grażyna Sobol-Milejska (Oddział Onkologii, Hematologii i Chemioterapii, Klinika Pediatrii, Śląski Uniwersytet Medyczny, Katowice); Jolanta Goździk (Ośrodek Transplantacji Uniwersyteckiego Szpitala Dziecięcego w Krakowie, Katedra Immunologii i Transplantologii Klinicznej, Uniwersytet Jagielloński Collegium Medicum, Kraków); Joanna Klepacka (Zakład Mikrobiologii, Uniwersytecki Szpital Dziecięcy, Kraków).

Author contributions: Jan Styczyński had primary responsibility for study design, data analysis and interpretation, statistical analysis and writing manuscript. All Authors contributed to data collection and data interpretation.

\section{ACKNOWLEDGEMENTS}

This paper was reviewed by dr hab. Lidia Gil, Department of Hematology, University of Medical Sciences, Poznan, and dr hab. Agnieszka Wierzbowska, Department of Hematology, Medical University, Łódź. 


\section{REFERENCES}

1. Gooley TA, Chien JW, Pergam SA, Hingorani S, Sorror ML, Boeckh M, Martin PJ, Sandmaier BM, Marr KA, Appelbaum FR, Storb R, McDonald GB: Reduced mortality after allogeneic hematopoietic-cell transplantation. N Engl J Med 2010;363:2091-2101.

2. Styczynski J, Gil L: Prevention of infectious complications in pediatric HSCT. Bone Marrow Transplant 2008;42 Suppl 2:S77-81.

3. Mikulska M, Del Bono V, Raiola AM, Bruno B, Gualandi F, Occhini D, di Grazia C, Frassoni F, Bacigalupo A, Viscoli C: Blood stream infections in allogeneic hematopoietic stem cell transplant recipients: Reemergence of Gram-negative rods and increasing antibiotic resistance. Biol Blood Marrow Transplant 2009;15:47-53.

4. Caselli D, Cesaro S, Ziino O, Zanazzo G, Manicone R, Livadiotti S, Cellini M, Frenos S, Milano GM, Cappelli B, Licciardello M, Beretta C, Arico M, Castagnola E: Multidrug resistant Pseudomonas aeruginosa infection in children undergoing chemotherapy and hematopoietic stem cell transplantation. Haematologica 2010;95:16121615.

5. Gil L, Styczynski J, Komarnicki M: Infectious complication in 314 patients after high-dose therapy and autologous hematopoietic stem cell transplantation: Risk factors analysis and outcome. Infection 2007;35:421-427.

6. Groll AH, Castagnola E, Cesaro S, Dalle JH, Engelhard D, Hope W, Roilides E, Styczynski J, Warris A, Lehrnbecher T: Fourth European Conference on Infections in Leukaemia (ECIL-4): Guidelines for diagnosis, prevention and treatment of invasive fungal diseases in paediatric patients with cancer or allogeneic haematopoietic stem cell transplantation. Lancet Oncol 2014; (in press)

7. Styczynski J: Diagnostyka i leczenie inwazyjnych zakażeń grzybiczych u dzieci: Rekomendacje pediatrycznej grupy ECIL-4. Zakażenia 2012;12:73-82.

8. Czyżewski K, Styczynski J, Krenska A, Debski R, ZajacSpychala O, Wachowiak J, Wysocki M: Intrathecal therapy with rituximab in central nervous system involvement of post-transplant lymphoproliferative disorder. Leuk Lymphoma 2013;54:503-506.
9. Styczynski J, Gil L, Tridello G, Ljungman P, Donnelly JP, van der Velden W, Omar H, Martino R, Halkes C, Faraci M, Theunissen K, Kalwak K, Hubacek P, Sica S, Nozzoli C, Fagioli F, Matthes S, Diaz MA, Migliavacca M, Balduzzi A, Tomaszewska A, Camara Rde L, van Biezen A, Hoek J, Iacobelli S, Einsele H, Cesaro S: Response to rituximab-based therapy and risk factor analysis in epstein barr virus-related lymphoproliferative disorder after hematopoietic stem cell transplant in children and adults: A study from the Infectious Diseases Working Party of the European group for Blood and Marrow Transplantation. Clin Infect Dis 2013;57:794802.

10. Styczynski J, Reusser P, Einsele H, de la Camara R, Cordonnier C, Ward KN, Ljungman P, Engelhard D: Management of HSV, VZV and EBV infections in patients with hematological malignancies and after sct: Guidelines from the second European Conference on Infections in Leukemia. Bone Marrow Transplant 2009;43:757-770.

11. Zaia J, Baden L, Boeckh MJ, Chakrabarti S, Einsele H, Ljungman P, McDonald GB, Hirsch H: Viral disease prevention after hematopoietic cell transplantation. Bone Marrow Transplant 2009;44:471-482.

12. Ljungman P, de la Camara R, Cordonnier C, Einsele H, Engelhard D, Reusser P, Styczynski J, Ward K: Management of CMV, HHV-6, HHV-7 and Kaposisarcoma herpesvirus (HHV-8) infections in patients with hematological malignancies and after SCT. Bone Marrow Transplant 2008;42:227-240.

Address for correspondence:

Jan Styczyński

Katedra Pediatrii, Hematologii i Onkologii

Collegium Medicum im. L. Rydygiera w Bydgoszczy

Uniwersytet Mikołaja Kopernika

ul. Curie-Skłodowskiej 9

85-094 Bydgoszcz

e-mail: jstyczynski@cm.umk.pl

Received: 14.03.2014

Accepted for publication: 6.05.2014 